\title{
THE CONTRIBUTING FACTOR THE LACK OF THEATRE FUNDING
}

\author{
Engku Munirah Nabihah Engku Abd Rahman \\ Faculty Film, Theatre and Animation, University Technology Mara \\ eng_muni92@yahoo.com \\ Received:10 March 2021 / Accepted: 25 April 2021
}

\begin{abstract}
This paper explores factors that influence theatre funding in Malaysia. It argues that as an indispensable resource, theatre funding is always inadequate. Financing from private or government initiatives has always been a topical and sensitive issue for government, associations, the corporate sector, donors and the local community. Research has found that funding is a major issue and problem faced by theatre production and activist. This research aimed to identify the factors that contribute to the lack of theatre funding. It is believed that strategic planning, financial management and marketing will contribute to financing based on the production goals. The research uses are qualitative, in nature and use interviews as its main information-gathering tools. Theatres should be directed to other sources of funding with appropriate strategies and approaches to fulfilling their mission.
\end{abstract}

Keywords: Theatre, financing, funding, strategies.

\section{INTRODUCTION}

Theatre would ensure financial stability and sustainability. Theatre production must have additional revenue which will be derived from the activities of ticket sales, paid workshop, rental (own facilities), souvenirs, training sources, etc. Kuesters (2010) explains that theatre, even from commercial sources such as income, donations and sponsorship should be financed and may not rely exclusively on income sources such as government funds.

Finance could be an important part of any program planning or art activity. Funding is one of the financings of theatre and sources of income for a theatre production. Finding the sources of funding for theatre production seems more challenging than ever. To get the funding, the theatre production needs to have funding strategies. Funding strategies don't work 
on their own, but they are doing must be a part of the general business plan or strategies that show where the organization is growing. A funding strategy is a written and agreed plan that determines an organization or group's financial requirements over time. Generally, funding theatre covers a three to five-year timescale and details the plans for the end of that period. It is a document that should outline how theatre production collects money and resources to fulfil the theatre production objectives. Production needs to be smart in solving a problem because every business needs a wise decision. Theatre is a business. A business could be creative work and also the production of something (Ibbotson, 2005).

\section{LITERATURE REVIEW}

Normally funding is that the one which makes every organization's life meaningful. All decisions and planning for each organization's future require fund which fund must be planned effectively so that a company are often a successful one (Brealey, Myer \& Marcus, 2001). The whole planning process is called financial planning, organizations have to make sure that they have strong financial planning and they have to execute well in their life so that they will emerge as a successful one. Finances are self-supporting documents designed to support and guide business actions (Smith, 2010). However, there has been a few of what the factor of the lack of theatre funding:

\section{a) Lack of Strategic Financial Planning Skills}

Strategic planning guides the future of the business by prioritizing and allocating resources to achieve the goals laid down in the plan (Barnend, 2011). When a company performs an appropriate strategic planning process daily, business performance is measured and evaluated. This method allows business owners and managers to dedicate resources to improved business performance and to implement changed business practices. With a strategy that is focused on constant improvement, the company will continue to thrive, but it means that several crises can also be identified and addressed before they harm the business.

As Ross and Kami (1998) have suggested that without a strategy the organization is like a ship without a rudder, going around in circles. It's like a tramp; it doesn't have a place to go. They attribute most business failures to a lack of strategy or the wrong strategy or the lack of a fairly good strategy. Successful companies are people with a clear objective, set goals and established procedures to achieve these goals consistently. 


\section{b) Lack of Financial}

Every theatre people understand the need for a fund to support their finance. Many theatres, supported by public resources, have far greater potential for facilities and even their professionals than their demands. Regardless of the continuing lack of financial resources and of the additional costs of keeping a theatre active for long hours (Lluis \& Hector, 2018). This is in part due to difficulties in attracting private funding or sponsorship and also because there is generally much less administrative experience in the Asian arts sector than in the mainstream, which means that they are less able to manage finances effectively and make successful lottery funding bids and the like.

\section{c) Lack of Understanding of How They Should Perceive Their Funder}

In Nathan \& Hallam's paper (2009), there seems to be a lack of understanding among artists of how they should perceive their sponsors, and that sometimes sponsors recognize the importance of founder ship. Sergeant (2002) noted that the relationship between the funder and the arts organization is also less pronounced in the arts, that limited attrition rates information is available and that studies do not appear to examine possible links between attrition rates and cultivation practices.

\section{d) Lack of Management Tools}

According to Bekker \& Staude (1996), to start with a clear understanding of the tasks and responsibilities of management to develop professional competence. Management tasks include organization, leadership and control. Managers fail to plan for their ignorance and lack of vision, lack of specific goals and ideals, lack of information on the future, lack of self-discipline and unable to stay close to the goals that they need. Ivana, Marija \& Ivana Tokic (2016) expressed a lack of management tools. The production of theatres must implement management tools in operating theatres that aim to achieve business efficiency. The importance of education for managers, because it is not possible to apply business models without proper education. In this respect, it is proposed that the reform of the system of financing for theatre should start with the theatre itself, which emphasizes education and training of theatre managers in the economic field, rather than the reform of financing. For this approach, management tools such as strategic planning, marketing, fundraising and financial management must be implemented which would ensure stable functioning, efficiency and economic efficiency in theatre operations. In addition to artistic skills, leaders need managerial skills and competencies. 


\section{e) Lack of Communication}

The fact that funders have cultivated an environment in which some artists can imitate the jargon and agendas of the funders to survive does not mean that meaningful communication is possible. Although millions of people are being thrown at this manifest lack of financial sustainability in the arts, it is also an indication of the lack of communication, but also that there is a community of "professional applicants" who lack the necessary sycophancy qualifications and organization merit.

\section{METHODOLOGY}

This research is qualitative and uses interviews as its main information-gathering tool. As a result, although have the funding strategies still have the factor why theatre production or group theatre or activist facing that issue to get the funding from government, corporate sector or another sources income.

\section{FINDINGS}

Based on the research, the result can identify some weaknesses in the production of artwork that may result in insufficient funds, including:

\section{a) Funding Start-Up}

The ministry is constantly changing. Each change has different policies according to the ministry. For example, will take the example of the National Cultural and Arts Department (JKKN) which trains, guides, disseminates, promotes and promotes the arts-culture efforts and is established below;

1950: Ministry of Social Welfare

1964: Ministry of Information

1972: Ministry of Culture, Youth and Sports

1987: Ministry of Tourism and Culture

1992: Ministry of Culture, Arts and Tourism \& Ministry of Culture, Arts and Heritage

2005: Improved to the Culture and Arts Department

For about 10 years until 2013, JKKN was housed in four different units, which were converted into one of the following agencies

Year 2008: Ministry of Culture and Heritage Unity Ministry 
Year 2009: Under the patronage of the Ministry of Information Communication and Culture (KPKK)

2013: A Ministry of Tourism and Culture agency

According to the informant interviewed, each ministry will have an allocation for cultural or artistic activities under their ministry. Theatre productions or theatre groups need to be well aware of and research the needs of a ministry to obtain funding from them.

\section{b) Paperwork or Proposal}

The presentation of the paper presented is very important due to every essence in it will determine a ministry or organization to provide funding or sponsorship. According to the informant interviewed, the paperwork or proposal represent the credibility of the production for a theatrical production. They use the same paperwork or proposal for approaches to funding and sponsorship. The contents did not put forwards such plans as theatrical performances for the second or third time. To convey is that the staging plan is not just one, but rather the annual plan. For example, the staging period is 4 months. This means that within a year, the production or theatre group will present three copies and this plan should be included in the paper. Besides, they stated that when submitting proposals or paperwork to the government, they did not receive feedback. Because of that, theatre production or group theatre or activist don't know their weaknesses when submitting the proposal to the government.

\section{c) Attitude}

All the informants interviewed expressed the attitude of the theatre people themselves which made it difficult for them to obtain funding and sponsorship from the requested party. Albarracian (2005), attitude can be characterized as a propensity to view a particular object or action with a degree of favour or disfavour. Minister of Communications and Culture Datuk Seri Dr Rais Yatim (2011), the government's commitment to the national creative industry's emphasis highlighted in Budget 2010, included the preparation of an RM200 million Creative Industry Fund to fund activities such as film and drama production, music, animation, advertising and development local content. This loan is managed by Bank Simpanan Nasional (BSN). For example, the researcher took the words from an informant, once production has approved the loan, unfortunately, they do not repay the loan. This is because the loans obtained are not properly planned for the use of the loan even though the theatre project has not received a 
positive return. She added that here we can see that the production planning was not done properly and as a result production could not repay the loan but it could even be bankrupt. In the event of such a situation, the amount of the budget run by BSN obtained by the government does not result in a return.

\section{d) Business Plan}

Theatre people or theatre groups lack skills in business or showbiz. The difficulties approaching business due to them not have business skills. Other than that, lack of proper planning is one of the problems in obtaining funding sources. If we look at how big theatres can survive it is because of the well-planned planning. Kuala Lumpur Performing Arts Center (KLPac) or The Actor Studio, for example, has an annual plan. Usually, they announce staging events that take place throughout the year. In our country, not many theatre groups or performers do so. In contrast to countries where the theatre industry is concerned, they will announce theatres to be staged at the beginning of autumn around September. Some performances will take place until the end of spring sometime in May depending on the production capability. In the summer, will last congress, festivals, theatre workshops and all activities that involve the community. Planning for the start of the new season also further refined before they announced plans new season.

\section{e) Return of Investment (ROI)}

All the informants interviewed; theatre production does not make Return of Investment (ROI) as the primary method in their business. They do not care about ROI. Theatre is a business. A successful business requires planning and a positive return. A few of the theatre groups present the theatre as a faction and not as a business. The ROI must be taken seriously by all theatre groups due to $\mathrm{ROI}$ is one of the most important elements in applying for a grant or sponsorship from a government or agency organization.

\section{DISCUSSION AND CONCLUSION}

Some key findings were identified through the study authors based on interviews and observations. Most of those involved in the theatre industry believe that theatre should get high financing by budgetary resources (government, private, corporate), and then by sponsorships and donations, and finally by their income. In addition, a theatre production that receives funding should provide: 
- Good financial resource management. This includes proper record keeping per applicable accounting standards and a strong financial process;

- Corporate governance practices need to be strong and active participation of members.

How funding can art be provided and viewed by an organization to provide funding for a production or theatre group, including;

\section{Quality of Content or Programs and Services}

Production or theatre groups must have a clear vision and commitment to achieve it. Providing content or essence/production/exhibition/performance of innovative, high artistic merit, contribute to achieving the vision and recognize the context of Malaysian arts and culture (eg. In the local or international settings)

\section{Governance and Management Capabilities}

The organization is as strong as its employees, from the institution to the artistic team and its management. Financing obtained is to let them have a clear organizational structure, invest effort in developing the skills of employees of their organizations, and if applicable, consider a substitution plan.

\section{Good Financial Advances}

Improving the financial viability and achieve better financial sustainability. This means better cash flow management, build a source of income, and being proactive in developing a customer base (e.g., supporters, donors, sponsors and volunteers). The researcher concluded that management tools in the business (e.g., marketing, strategic planning, financial management, fund-raising) will ensure a stable operation, including market success, cost-effectiveness, operations theatre's efficiency and market-based development. To achieve this, skill management and efficiency must be in line with artistic skills.

The role of the government also plays a task in helping to accelerate the event of theatre arts in Malaysia. Theatre has never been seen as a very important and wasteful branch of art. Theatre plays a task in shaping the culture, the reflection of civilization, the thinking and also the realm of social development. The government has essentially continued to elevate the prestige of theatrical arts compared to other arts industries like music and film. Theatre isn't nearly entertainment. In developed countries, theatrical knowledge has been explored 
to the extent that it can function as an outgrowth of psychodrama, sociodrama and dramatization. With the more serious role of the govt. and also the private sector, funding for the theatre are going to be more organized and can increase the country's income.

Next, the government and also the private sector must review development expenditure and provisions for cultural, arts and heritage programs. This can be because, if the theatre can continue, production crews or behind-the-scenes workers and art practitioners who target working within the theatre, can receive a considerable source of income. Potential private companies are encouraged to produce a resource for production or theatre groups to thrive and perform quality and outstanding performances.

In conclusion, these scholarly writings prove that theatre requires government funding. Given that there are insufficient budgetary allocations for cultural institutions, they must not rely on these sources of funding. Theatre should be directed to other funding sources using appropriate strategies and approaches to fulfilling their mission. Theatre production should conduct activities aimed at diversifying the sources of funding and ensuring financial stability by increasing the share of business funding (through sponsorships and donations), as well as the theatre products and services sales (revenue). It is also proposed that the reform of the theatre funding system should begin "from the bottom up," that is from the theatre itself, with a focus on education and training of theatre managers in the economic field to enable management and financing to be more efficient.

\section{REFERENCES}

Albarracin, D. (2005). Attitudes: Introduction and scope. In The Handbook of Attitudes. UK: Psychol. Press.

Barned, J. (2011).

Improving business Performance. CPA Australia Ltd: Australia.

Bekker, F., \& Staude, G. (1996). Starting and managing a small business. Kenwyn: Juta $\&$ Co.

Brealey, R. A. (2001). Fundamentals of corporate finance. USA: McGraw-Hill

Companies, Inc. (1992). Corporate Strategy, Structure and Control Methods. The USA Analysis Journal, 66 (May/June 2010), 45-59.

Bonet, L., \& Schargorodsky, L. (2018). Theatre management: Models and strategies for cultural venues. Norway: National Centre for Cultural Industries.

Bukvic, B. I, Mihaljevic, M., \& Tokic, I. (2016). Financing the theatre: The role of management and the state. Econviews, 29 (1), 125-142.

Ibbotson, P. (2005). Directing creativity: The art and craft of creative leadership. Journal of Management and Organization, 14(5), 548-559. 
Kuesters, I. (2010). Arts managers as liaisons between finance and art: A qualitative study inspired by the theory of functional differentiation. The Journal of Arts Management, Law, and Society, 40 (1), 43-57.

Nathan, A., \& Hallam, L. (2009). A qualitative investigation into the donor lapsing experience. International Journal of Nonprofit and Voluntary Sector Marketing, 14(4), 317-331.

Sargeant. (2002). Major Gift Philanthropy - Individual Giving to the Arts. Centre for Voluntary Sector Management, Arts \& Business. http://www.artsandbusiness. org.uk/media\%20library/Files/Research/Philanthropy.pdf.

Ssekatawa, S. (2010). Managing Partner at Momentum Capital and Backbone Business Investment Services. Uganda: Shell

Ross, J., \& Kami, M. (1998). Strategic management: Concept and case. The Strategic Management Process. USA: McGraw-Hill Companies, Inc. 


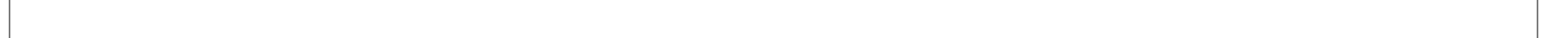

